\title{
Inovasi Mie Basah Dengan Penambahan Tepung Kacang Hijau Terhadap Daya Terima Konsumen
}

\author{
Annisa Tiffani ${ }^{\mathbf{1}}$, Caria Ningsih ${ }^{\mathbf{1}}$, Mandradithya Kusuma $\mathbf{P}^{\mathbf{2}}$ \\ ${ }^{1}$ Manajemen Industri Katering, Fakultas Pendidikan Ilmu Pengetahuan Sosial, Universitas \\ Pendidikan Indonesia, Jl. Dr. Setiabudhi No. 229, Bandung 40154, Indonesia \\ ${ }^{2}$ Food and Beverage Service, Sekolah Tinggi Pariwisata Bandung, Jl. Dr. Setiabudi No.186, \\ Hegarmanah, Kec. Cidadap, Kota Bandung, Jawa Barat 40141 \\ * Koresponding Penulis. E-mail: annisatiffani@student.upi.edu (Annisa Tiffani)
}

\begin{abstract}
Abstrak
Inovasi produksi mie basah dengan menambahkan tepung kacang hijau adalah cara untuk mengurangi konsumsi tepung di Indonesia. Penelitian ini bertujuan untuk meningkatkan keragaman inovasi kuliner terutama pada mie, untuk mengetahui formulasi mie basah dengan penambahan tepung kacang hijau. (MTKH), uji yang diterima konsumen, dan biaya produksi mie basah. Metode yang digunakan dalam penelitian ini adalah eksperimental. Langkah pertama yang diambil adalah membuat perbandingan antara tepung terigu resep standar dengan tepung kacang hijau adalah 50\% MTKH1: MTKH2 50\% dan 70\%: 30\%. Tes pertama adalah tes organoleptik untuk panelis ahli sebanyak 15 orang di mana tes ini diperoleh dari sampel MTKH2 sampel yang terbaik dengan peringkat rata-rata 4,04 sedangkan MTKH1 mendapatkan nilai sampel 3,36. Setelah mendapatkan langkah terbaik berikutnya adalah tes yang diterima konsumen. Tes penerimaan konsumen ini melibatkan sebanyak 100 panelis, dengan skor 2078, kemudian mie basah tepung kacang hijau diterima oleh konsumen, diwakili oleh 100 responden.
\end{abstract}

Kata Kunci: $\quad$ Mie; Tepung Kacang Hijau; Tes Organoleptik; Tes yang Diterima Konsumen

\section{Pendahuluan}

Mie salah satu produk makanan dengan bahan baku tepung terigu sangat popular dikalangan masyarakat Indonesia. Produk mie umumnya digunakan sebagai sumber energi karena memiliki karbohidrat yang cukup tinggi. Mie juga merupakan salah satu jenis makanan alternatif setelah nasi yang perkembangannya sangat cepat. Mie berkembang dari waktu kewaktu dari segi jumlah maupun variasinya. Mie telah lama digunakan dalam kuliner Indonesia. Hal ini tampak dalam berbagai resep masakan tradisional yang menggunakan mie sebagai bahan dasarnya, seperti aneka soto, mie juhi betawi, mie celor palembang, dan lain-lain.

Mie basah sendiri adalah mie mentah yang sebelum dipasarkan mengalami proses perebusan dalam air mendidih, denga kadar air sekitar 35\% dan setelah direbus kadar airnya meninkat menjadi 52\% (Koswara, 2009:12). Selama ini mie dibuat dengan tepung terigu, terigu merupakan produk pangan yang bisa dikatakan memenuhi hajad hidup orang banyak karena tingkat konsumsi masyarakat

Indonesia terhadap produk berbahan dasar terigu cukup besar dan semakin meningkat dari tahun ke tahun. Indonesia memiliki konsumsi yang besar terhadap produk tepung terigu, sedangkan kapasitas produksi tepung terigu di Indonesia masih rendah. Bahan baku tepung terigu berasal dari biji gandum sehingga ketersediannya ditentukan oleh produksi pertanian gandum. Gandum merupakan tanaman subtropis, sedangkan Indonesia adalah negara tropis sehingga tanaman gandum kurang bisa 
tumbuh optimal di Indonesia. Peningkatan permintaan terigu karena semakin beragamnya produk makanan berbasis terigu. Akibatnya ketika harga terigu naik para produsen makanan olahan menghadapi masalah yang berat. Salah satu solusi untuk mengatasi masalah tersebut adalah memanfaatkan bahan pangan serealia lain untuk substitusi tepung terigu. Mie bisa ditambahkan dengan tepung lain yang mempunyai komposisi hampir sama dengan tepung terigu, yaitu tepung kacang hijau yang mengandung karbohidrat dan protein yang lebih tinggi.

Tepung kacang hijau merupakan tepung yang terbuat dari kacang hijau. Di Indonesia produksi kacang hijau sangat berlimpah, produksi kacang hijau yang cukup tinggi bisa menjadi potensi besar untuk masyarakat dalam pemanfaatan kacang hijau menjadi berbagai macam produk. Namun produksi kacang hijau tidak sebanding dengan konsumsi kacang hijau itu sendiri. Oleh karena itu salah satu cara pemanfaatan kacang hijau

dengan menjadikannya tepung kacang hijau. Tepung kacang hijau merupakan salah satu tepung yang bebas gluten yang berasal dari biji kacang hijau. Tepung kacang hijau dapat digunakan sebagai produk mie yang kaya akan kandungan kalsium, magnesium dan phosphor. Denganpenggunaan $10 \%$

tepung kacang hijau dalam tepung terigu dapat menghasilkan mie yang bernilai gizi lebih baik dengan warna, bau dan cita rasa yang dapat diterima konsumen. Tepung kacang hijau dapat dijadikan alternatif bahan baku yang dapat digunakan sebagai bahan pencampuran di dalam pembuatan mie. Tepung kacang hijau mengandung protein yang lebih tinggi dari tepung terigu.

Inovasi pengolahan makanan yang berbahan baku tepung kacang hijau masih terbatas. Maka dari itu dibutuhkan sebuah inovasi yang dapat memanfaatkan potensi, serta kelebihan yang dimiliki oleh kacang hijau. Inovasi harus ditujukan pada pembaharuan dan penemuan produk yang diharapkan terbuat dari bahan yang murah, cara mengolah dan menyajikan dengan cara yang ekslusif.

Adapun rumusan masalah dari latar belakang tersebut adalah:

a. Bagaimana formulasi resep mie dengan penambahan tepung kacang hijau?

b. Bagaimana formulasi penambahan tepung kacang hijau yang terbaik dengan skala perbandingan 50:50 dan 70:30?

c. Bagaimana daya terima konsumen terhadap mie dengan penambahan tepung kacang hijau?

Dari rumusan masalah diatas maka diketahui tujuan dari penelitian ini adalah untuk mengetahui formulasi resep mie basah dengan penambahan tepung kacang hijau, untuk mengetahui formulasi terbaik dengan skala perbandingan 50:50 dan 70:30, serta untuk mengetahui bagaimana daya terima terhadap konsumen.

Inovasi adalah pengetahuan untuk menghasilkan pengetahuan yang baru, inovasi menjadi kunci kewirausahaan dimana kewirausahaan merupakn upaya untuk menciptakan perubahan yang direncanakan terfokus dalam sebuah perusahaan maupun dalam tatanan masyarakat (Taufik, 2011:231). Sedangkan menurut Selamet (2014:7) Inovasi adalah kemampuan untuk mengimplemantasi ide ide kreatif terhadap permasalahan dan peluang yang ada untuk meningkatkan dan memperkaya kehidupan orang. Inovasi harus ditujukan pada pembaharuan dan penemuan produk yang diharapkan terbuat dari bahan yang murah, cara mengolah dan menyajikan dengan cara yang ekslusif.

Mie merupakan salah satu jenis masakan yang sangat populer di Asia, khususnya Asia Timur dan Asia Tenggara. Di Benua Eropa, mie mulai dikenal setelah Marcopolo berkunjung ke Cina dan membawa oleh-oleh mie. Selanjutnya, mie berubah menjadi pasta di Eropa (Suyanti, 2008:5). Menurut Badan Standarisasi Nasional (1992), mie adalah produk pangan yang terbuat dari terigu dengan atau tanpa penambahan bahan pangan lain dan bahan 
tambahan pangan yang diizinkan, berbentuk khas mie. Sekitar $40 \%$ kosumsi gandum di Asia adalah mie.

Menurut Astawan (2006:16), ada empat jenis mie, yaitu:

\section{a. Mie Segar}

Mie ini merupakan mie yang tidak mengalami proses tambahan setelah pemotongan dan mengandung air sekitar $35 \%$. Oleh karena itu, mie ini cepat rusak dan hanya mampu bertahan 24 jam di suhu ruang $\left(27^{\circ} \mathrm{C}\right)$. Mie ini umumnya dibuat dari tepung terigu yang keras agar mudah penanganannya.

\section{b. Mie Basah}

Mie basah adalah jenis mie yang mengalami proses perebusan setelah tahap pemotongan dan sebelum dipasarkan. Kadar airnya dapat mencapai $52 \%$ sehingga daya tahan simpannya relatif singkat (40 jam suhu kamar). Di Indonesia, mie ini dikenal sebagai mie kuning atau mie bakso.

\section{c. Mie Kering}

Mie kering adalah mie segar yang telah dikeringkan hingga kadar airnya 8$10 \%$. Pengeringan umumnya dilakukan dengan penjemuran di bawah sinar matahari atau dengan oven. Karena bersifat kering maka mie ini memiliki umur simpan yang lama hingga mencapai 6 bulan dalam kemasan yang kedap dan rapat. Mie kering sebelum dipasarkan biasanya ditambahkan telur segar atau tepung telur, sehingga mie ini dikenal juga dengan nama mie telur.

\section{d. Mie Instan}

Mie instan sering juga disebut dengan ramen. Mie ini dibuat dengan penambahan beberapa proses setelah diperoleh mie segar. Tahap-tahap itu yaitu pengukusan, pembentukan dan pengeringan. Kadar air mie instan biasanya 5,8\% sehingga daya simpannya lama hingga 1 tahun dalam kemasan yang kedap dan rapat.

Mie basah sendiri adalah mie mentah yang sebelum dipasarkan mengalami proses perebusan dalam air mendidih, denga kadar air sekitar 35\% dan setelah direbus kadar airnya meninkat menjadi 52\% (Koswara,2009:12). Mie basah miliki kadar air mencapai $52 \%$ sehingga daya tahan simpannya relatif singkat. Mie basah merupakan jenis mie yang mengalami proses perebusan setelah tahap pemotongan dan sebelum dipasarkan. Biasanya mie basah dipasarkan dalam keadaan segar. Mie basah di Indonesia dikenal sebagai mie kuning atau mie bakso. Adapun bahanbahan pembuatan mie sebagai berikut : Tepung Terigu. Air, Garam, Telur, Minyak.

Kacang hijau merupakan sejenis tanaman budidaya dan palawijaya yang dikenal luas didaerah tropika. Tumbuhan yang termasuk suku polong-polongan (Fabaceae) ini memiliki banyak manfaat dalam kehidupan sehari-hari sebagai sumber bahan pangan berprotein nabati tinggi. Dalam perdagangan di Indonesia hanya dikenal dua macam mutu, yaitu kacang hijau biji besar dan biji kecil. Kacang hijau biji besar digunakan untuk bubur dan tepung, sedangkan yang berbiji kecil digunakan untuk pembuatan taoge (Purwono, 2012:12). Kacang hijau merupakan sumber protein, mieneral, kalsium, asam folat, potasium dan magnesium yang sangat baik. Kacang hijau juga mengandung tiamien, asam pantotenat, zat besi, fosfor, seng dan tembaga. Dari kandungan gizi dari kacang hijau, kacang hijau sering di buat produk olahan seperti bubur kacang hijau, minuman sari kacang hijau dan bisa di kembangkan menjadi minuman instan kacang hijau. Di cina tepung kacang hijau digunakan pada pembuatan mie instan (Wirakusumah, 2010:14). Dalam setiap 100 gram biji kacang hijau mengandung 345 kal kalori, 22 gram protein, 1,2 g lemak, 62,9 $\mathrm{g}$ karbohidrat, $125 \mathrm{mg}$ kalsium, $320 \mathrm{mg}$ fosfor $6,7 \mathrm{mg}$ besi, $157 \mathrm{SI}$ vitamin A, 0,64 mg vitamin $\mathrm{B} 1,6 \mathrm{mg}$ vitamin $\mathrm{C}$ dan $10 \mathrm{~g}$ air (Mustakim, 2014:60).

Tabel 1. Kandungan Gizi Kacang Hijau

\begin{tabular}{lc}
\hline \multicolumn{1}{c}{ Uraian } & $\begin{array}{c}\text { Kandungan } \\
\text { Gizi }\end{array}$ \\
Kalori $(\mathrm{g})$ & 345 \\
Protein $(\mathrm{g})$ & 22 \\
Lemak $(\mathrm{g})$ & 1.2 \\
Karbohidrat $(\mathrm{g})$ & 62.9 \\
Air $(\mathrm{g})$ & 10 \\
\hline
\end{tabular}




\begin{tabular}{lc}
\hline \multicolumn{1}{c}{ Uraian } & $\begin{array}{c}\text { Kandungan } \\
\text { Gizi }\end{array}$ \\
\hline Kalsium (g) & 125 \\
Fosfor (mg) & 320 \\
Zat Besi (mg) & 6.7 \\
Vitamin A (SI) & 157 \\
Vitamin B1 (mg) & 0.64 \\
Vitamin C (mg) & 6 \\
\hline
\end{tabular}

Sumber : M. Mustakim, 2014:60

Tepung kacang hijau merupakan butiran-butiran halus yang berasal dari kacang hijau kering yang digiling dalam bentuk tepung dan akan memudahkan penggunaannya untuk bahan baku industri makanan (Komah, 2013:26) Menurut Mustakim (2014:46) tepung kacang hijau sangat bergizi untuk pertumbuhan. Hal ini dikarenakan tepung kacang hijau mengandung gizi, baik protein, lemak, maupun asam aminonya. Tepung kacang hijau juga mengandung senyawa anti gizi antara lain antitrypsin, lektin dan asam fitat. Antitripsin adalah suatu senyawa yang dapat menghambat aktivitas enzim tripsin didalam saluran pencernaan. Lektin adalah suatu senyawa yang dapat menggumpalkan sel darah merah. Sedangkan asam fitat adalah sumber phospor namun tidak dapat dicerna didalam tubuh. Namun dari sejumlah penelitian mengatakan bahwa perendaman dapat menginaktifkan senyawa ini. Peneliti melakukan percobaan untuk membuat tepung dari kacang hijau sebagai salah satu penambahan bahan baku dalam pembuatan produk, berikut proses pembuatan tepung kacang hijau:

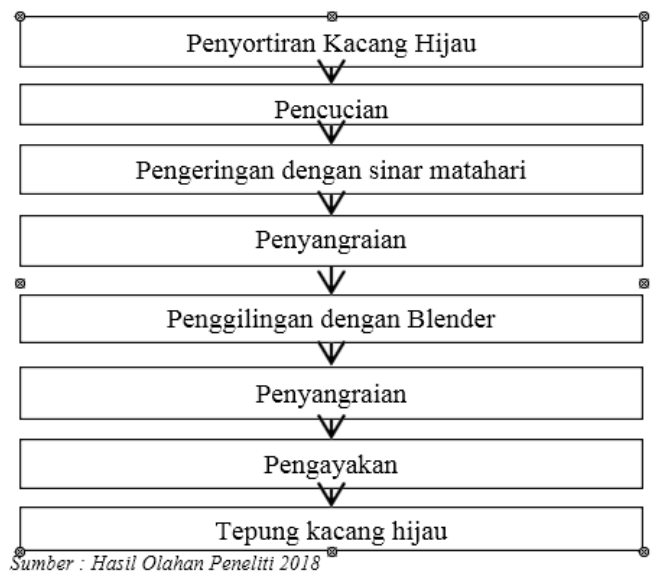

Gambar 1. Alur Pembuatan Tepung Kacang Hijau
Pengujian organoleptik disebut penilaian indera atau penilaian sensorik merupakan suatu cara penilaian dengan memanfaatkan panca indera manusia untuk mengamati tekstur, warna, bentuk, aroma, rasa suatu produk makanan. Pengujian organoleptic berperan penting dalam pengembangan produk. Evaluasi sensorik dapat digunakan untuk menilai adanya perubahan yang dikehendaki atau tidak dalam produk formulasi, mengidentifikasi area untuk pengembangan, mengevaluasi produk pesaing, mengamati perubahan yang terjadi selama proses, dan memberikan data yang diperlukan untuk produk (Nasiru, 2011:47)

Dalam penelitian ini, penulis menggunakan uji kesukaan yang merupakan bagian dari uji organoleptik. Menurut Sofiah dan Achsyar (2011:105), uji kesukaan atau uji hedonik merupakan uji dimana panelis diminta memberi tanggapan secara pribadi tentang kesukaan atau ketidaksukaan beserta tingkatannya. Tingkat-tingkat kesukaan ini disebut skala hedonik. Misalnya dalam hal "suka", dapat mempunyai skala hedonik seperti amat sangat suka, sangat suka, suka, agak suka. Sebaliknya jika tanggapan itu "tidak suka", dapat mempunyai skala hedonik seperti amat sangat tidak suka, sangat tidak suka, tidak suka, agak tidak suka. Di antara agak tidak suka dan agak suka kadang-kadang ada tanggapan yang disebut sebagai netral, yaitu bukan suka tetapi juga bukan tidak suka (neither like not dislike).

"Uji konsumen banyak digunakan karena terbukti sebagai alat yang efektif dalam dalam upaya pengembangan produk dan jasa yang akan dijual dalam jumlah yang lebih besar." (Setyaningsih ,2010:119). Uji penerimaan konsumen ini menyangkut pada penilaian seseorang mengenai kualitas suatu produk yang menyebabkan orang menyenangi produk tersebut. Pada uji ini panelis mengemukakan tanggapan mengenai suka atau tidak sukanya terhadap kualitas produk yang dinilai. Tujuan dari uji daya terima konsumen yaitu untuk 
mengetahui apakah suatu produk baru dapat diterima atau tidak oleh masyarakat. Uji daya terima konsumen atau yang biasa disebut sebagai uji penerimaan dilakukan dengan menggunakan uji hedonik atau uji kesukaan kepada panelis tidak terlatih yang memiliki tujuan untuk mendapatkan tingkat kesukaan suatu produk atau seberapa besar produk tersebut dapat diterima oleh masyarakat.Pada tahap ini data yang didapat merupakan hasil dari jawaban kuisioner yang disebarkan kepada panelis konsumen, penilaian berdasarkan kepada lima kriteria (rasa, aroma, warna, tekstur, dan penampilan) dari dua produk yang diberikan. Data yang telah terkumpul kemudian dianalisa menggunakan teknik analisa deskriptif.

Untuk melaksanakan penilaian organoleptik diperlukan panel. Dalam penilaian suatu mutu atau analisis sifat-sifat sensorik suatu komoditi, panel bertindak sebagai instrument atau alat. Menurut Ayustaningwarno (2014:2) panelis adalah anggota panel atau orang yang terlibat dalam pengujian organoleptic yang dari berbagai kesan subjektif produk yang disajikan.

Ada 6 macam panel yang biasa digunakan dalam penilaian organoleptik yaitu sebagai berikut.

a. Panel pencicip perorangan (individual expert)

Panel pencicip perseorangan juga disebut pencicip tradisional. Pencicip perseorangan ini mempunyai kepekaan yang sangat tinggi, jauh melebihi kepekaan ratarata manusia. Tingkat kepekaan ini diperoleh selain dari pembawaan lahir, juga dari pengalaman dan latihan yang lama. Ketajaman atau kepekaan ini biasanya hanya terhadap satu jenis komoditi. Keistimewaan seorang pencicip ini adalah dalam waktu singkat ia dapat menilai pengaruh dari macam-macam perlakuan, misalnya bahan asal, macam-macam pengolahan.

b. Panel pencicip terbatas (small expert panel)

Untuk menghindari ketergantungan pada pencicip perorangan maka beberapa industry menggunakan 3-5 orang penilai yang mempunyai kepekaan tinggi yang disebut panel terbatas. Biasanya panel ini diambil dari personal laboratorium yang sudah mempunyai pengalaman luas akan komoditi tertentu.

c. Panel terlatih (trained panel)

Anggota panel terlatih lebih besar daripada panel pencicip terbatas, yaitu antara 15-25 orang. Anggotanya tidak hanya personal laboratorium tetapi dapat pula karyawan atau pegawai lain. Tingkat kepekaan yang diharapkan tidak perlu setinggi panel pencicip terbatas, sedang tugas penilaian dan tanggung jawabnya juga tidak sebesar panel pencicip terbatas. Untuk menjadi anggota panel ini perlu diseleksi dan yang terpilih kemudian dilatih. Panel terlatih ini juga berfungsi sebagai alat analisis, dan pengujian yang dilakukan biasana terbatas pada kemampuan membedakan. Di sini diperlukan cukup banyak jumlah anggota panelis agar data penilaian dapat dianalisis secara statistik.

d. Panel tak terlatih (untrained panel)

Jika panel terlatih biasanya untuk menguji pembedaan (difference test), maka panel tak terlatih umumnya untuk menguji kesukaan (preference test). Demikian juga hal pemilihan anggota, panel terlatih diambil dari pegawai, sedangkan panel tidak terlatih diambil dari luar. Pemilihan yang dilakukan bukan terhadap kepekaan calon anggota tetapi pemilihan itu lebih mengutamakan segi sosial seperti latar belakang pendidikan, asal daerah kelas ekonomi dalam masyarakat, dan sebagainya.

e. Panel agak terlatih (semi-trained panel)

Panelis untuk panel agak terlatih jumlahnya terletak di antara panelis terlatih dan panelis tidak terlatih. Jumlah itu berkisar antara 15-25 orang. Makin kurang terlatih makin besar jumlah panelis yang diperlukan. 
f. Panel konsumen (consumer panel)

Panel ini biasanya mempunyai anggota yang besar jumlahnya, dari 30 sampai 1000 orang. Pengujiannya biasanya mengenai uji kesukaan (preference test) dan dilakukan sebelum pengujian pasar. Hasil uji kesukaan dapat digunakan untuk menentukan apakah suatu jenis makanan dapat diterima oleh masyarakat. Tetapi uji dengan panel konsumen tidak menggambarkan kesediaan konsumen untuk membeli makanan itu.

\section{Metode Penelitian}

Metode yang digunakan pada penelitian ini adalah metode penelitian eksperimental. Metode penelitian eksperimen dapat diartikan sebagai metode penelitian yang digunakan untuk mencari pengaruh perlakuan tertentu terhadap yang lain dalam kondisi yang terkendalikan (Sugiyono, 2014:72). Untuk mendapatkan standar resep yang sesuai dengan yang diinginkan peneliti melakukan eksperimen berupa kitchen project. Dalam kitchen project ini peneliti melakukan perbandingan 2 sampel mie kacang hijau dengan produk kontrol. Dimana pada sampel tersebut mendapatkan 2 perlakuan yang berbeda yaitu:

a. Mie dibuat dengan perbandingan tepung 50\%:50\%, dimana 50\% tepung terigu dan 50\% tepung kacang hijau.

b. Mie dibuat dengan perbandingan tepung 70\%:30\%, dimana $70 \%$ tepung terigu dan 30\% tepung kacang hijau.

Setelah melakukan kitchen

project kemudian dilakukan uji organoleptik kepada 15 panelis terlatih. Penilaian ini diberikan berdasarkan lima karakteristik yaitu, warna, penampilan fisik, tekstur, rasa dan aroma sehingga dihasilkan suatu formulasi terbaik dari berbagai perlakuan.

Kemudian dilakukan uji daya terima konsumen yaitu, memberikan produk terpilih kepada 100 orang konsumen beserta kuesioner untuk mengetahui hubungan antara variabel mutu organoleptik dan minat beli serta apa yang menjadi pengaruh dari karakteristik mutu organoleptik sehingga konsumen tertarik untuk mengkonsumsi mie berbasis tepung kacang hijau.

Teknik penarikan sampel yang digunakan untuk panelis terlatih adalah teknik sampling purposive,sedangkan untuk menentukan 100 orang panelis konsumen peneliti menggunakan teknik simple random sampling.

Teknik pengumpulan data dalam penelitian ini adalah :

a. Studi literature.

b. Teknik eksperimen.

c. Teknik kuisioner atau angket.

d. Teknik dokumentasi.

e. Teknik pencatatan.

Setelah data terkumpul hal yang dilakukan selanjutnya adalah menganalisis data. Teknik analisis dala yang digunakan dalam penelitian ini adalah dengan menggunakan Analysis of Variance (ANOVA) untuk menguji apakah ada perbedaan nyata antara rata-rata hitung tiga kelompok atau lebih.

\section{Hasil dan Pembahasan}

\subsection{Pembuatan Mie Tepung Kacang Hijau.}

Mie Basah Tepung Kacang Hijau memiliki karakteristik yang berbeda dari mie basah yang tidak memiliki tambahan tepung kacang hijau. Mie basah yang biasa memiliki tekstur licin, dan berwarna putih berbeda jika ditambahkan tepung kacang hijau. Mie basah yang diberi tambahan tepung kacang hijau akan memiliki warna kehijauan, semakin banyak tepung kacang hijau yang ditambahkan maka semakin pekat warnanya. Rasa dan aroma dari mie basah ini memiliki aroma khas kacang hijau.

\subsection{Pembuatan adonan}

Sesuai dengan formulasi tepung terigu (50gr dan 70gr) dicampur dengan tepung kacang hijau (50gr dan 30gr) sehingga total dari masing-masing campuran sebanyak $100 \mathrm{gr}$, garam $15 \mathrm{gr}$, telur 1 butir, minyak $1 / 2$ sdm, aduk adonan dengan tambahan air 
sedikit demi sedikit. Kemudian diamkan adonan.

\subsection{Penggilingan}

Adonan yang telah didiamkan kemudian di pipihkan kemudian adonan digiling menggunakan penggilingan mie hingga mendapatkan tekstur dan ketebalan yang diinginkan. Kemudian potong adonan mie dengan cetakan mie. Lalu diamkan serta beri taburan tepung agar mie tidak lengket.

\subsection{Penyajian}

Setelah mie didiamkan, rebus mie selama 5 menit hingga semua matang, lalu taruh dipiring saji.

\subsection{Pengujian Organoleptik}

Pada penelitian ini karakteristik yang diujikan dalam uji organoleptik difokuskan pada lima kriteria penilaian, diantaranya warna, aroma, rasa, tekstur dan bentuk (penampilan fisik produk). Pada pengujian ini peneliti memberikan 2 sampel berbeda kepada panelis ahli ,kemudian didapat hasil rata-rata dari ANOVA dan Test of Homogeity of Variances dengan selang kepercayaan $95 \%$ atau 0,5 sebagai berikut :

Tabel 2. Hasil Rata-Rata Uji Organoleptik

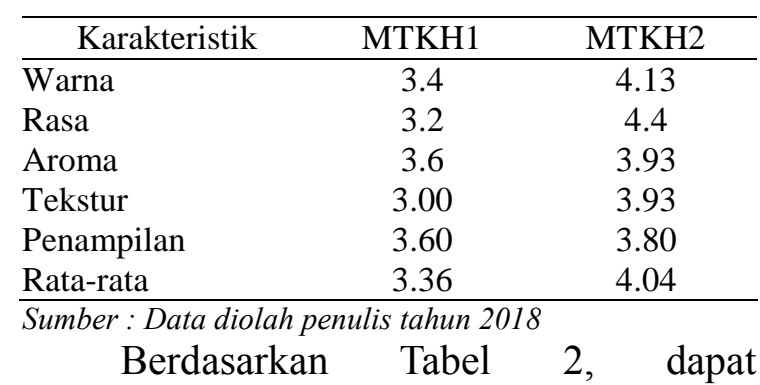

disimpulkan bahwa produk MTKH2 memiliki nilai rata-rata tertinggi diantara 2 sampel yang diberikan yaitu 4,04 dimana nilai rata-rata dari karakteristik yang diuji yaitu : warna 4,13 , rasa 4,4 , aroma 3,93 , tekstur 3,93, penampilan 3,80.

\subsection{Pengujian Daya Terima Konsumen}

Tahapan ini merupakan tahapan dimana responden yang berperan sebagai konsumen menanggapi dan menilai produk mie basah berbasis tepung kacang hijau dengan konsentrasi terbaik. Penilaian dilihat dari aspek tingkat kesukaan warna, penampilan, aroma, tekstur, rasa. Berdasarkan total skor dari hasil pengumpulan data pada variable daya terima konsumen MTKH2 sebanyak 2078 point, seperti pada tabel berikut:

Tabel 3. Hasil Uji Daya Terima Konsumen

\begin{tabular}{lc}
\hline \multicolumn{1}{c}{ Aspek } & Skor \\
\hline Rasa & 425 \\
Tekstur & 431 \\
Aroma & 439 \\
Warna & 360 \\
Penampilan & 423 \\
Jumlah & 2078 \\
\hline Sumber : data diolah penulis tahun 2018
\end{tabular}

Tabel 4. Kelas Interval Daya Terima Konsumen

\begin{tabular}{cc}
\hline Skor & Keterangan \\
\hline $500-900$ & Sangat tidak diterima \\
$901-1300$ & Tidak diterima \\
$1301-1700$ & Kurang diterima \\
$1701-2100$ & Diterima \\
$2101-2500$ & Sangat diterima \\
\hline
\end{tabular}

Sumber : data diolah penulis tahun 2018

Berdasarkan Tabel 4, dapat dilihat bahwa hasil perhitungan daya terima konsumen secara keseluruhan mendapatkan skor 2078 dan termasuk ke dalam kelas interval 1701-2100, maka produk mie basah kacang hijau termasuk ke dalam kategori dapat diterima oleh responden.

\section{Kesimpulan}

Tepung kacang hijau digunakan sebagai bahan tambahan tepung terigu dalam pembuatan mie basah. Bahan tambahan lainnya sama tidak ada perbedaan hanya perbedaan terdapat pada tepung. Penambahan tepung dibagi menjadi dua yaitu perbandingan $50 \%$ tepung terigu : $50 \%$ tepung kacang hijau, dan $70 \%$ tepung terigu : $30 \%$ tepung kacang hijau. Penggunaan tepung kacang hijau sesuai dengan perbandingan tersebut. Kemudian tepung terigu, tepung kacang hijau, dan garam dicampur kedalam satu wadah 
kemudian aduk, lalu masukan bahan cair seperti telur aduk hingga rata tambahkan air sedikit demi sedikit aduk hingga adonan menjadi kalis kemudian diamkan adonan sekitar 30 menit, setelah itu giling adonan hingga pipih sampai pada ketebalan yang diinginkan kemudian potong mie dengan pemotong mie, mie siap untuk diolah.

Terdapat 2 sampel pada percobaan yaitu MTKH1 (50:50) dan MTKH2 (70:30). Hasil terbaik pada produk mie basah tepung kacang hijau dengan uji organoleptik kepada para panelis ahli yang terdiri dari chef, guru, dan pengusaha ditunjukan oleh kode MTKH2 dengan nilai rata-rata 4,04, sedangkan MTKH1 mendapat nilai rata-rata 3,36, nilai tersebut berdasarkan nilai keseluruhan mulai dari rasa,aroma,tekstur,warna dan penampilan.

Uji daya terima konsumen yang dilakukan terhadap 100 responden yang berasal dari kalangan yang berbeda, baik dari segi usia, pekerjaan, pendidikan , hingga jumlah pendapatan. Hasil yang didapat dari uji coba penilaian terhadap daya terima mendapatkan nilai dengan jumlah keseluruhan 2078 dikategorikan diterima oleh responden yang berada di kelas interval 1701-2100.

\section{Daftar Pustaka}

Astawan, M. (2009). Sehat dengan Hidangan Kacang dan Biji-bijian. Jakarta: Swadaya.

Ayustaningwarno,

Fitriyono. 2014.Teknologi Pangan: Teori Praktis dan Aplikasi.Yogyakarta: Graha Ilmu.

Cahyono, B. (2007). Kacang Hijau (Teknik Budi Daya dan Analisis Usaha Tani). Semarang: Aneka Ilmu.

Komah, IR dan Kristiastuti, D. 2013. Pengaruh Substitusi Tepung Kacang Hijau Terhadap Tingkat Kesukaan Kue Jongkong. E-Journal Boga.02(03): 18-24

Koswara, S. (2009). Teknologi pembuatan Mie. Jakarta: Pustaka Sinar Harapan

Mustakim, M. (2012). Budi Daya Kacang Hijau Secara Intensif. Yogyakarta:
Pustaka Baru Press.

Nasiru,M. (2011). Effect of Cooking Time and Potash Concentration on Organoleptic Properties of Red and White Meat dalam Ayustaningwarno, F.2014.Teknologi Pangan; Teori

Praktis dan Aplikasi. Graha Ilmu.Yogyakarta

Purwono, MS \&Rudi Hartono. (2012). Kacang Hijau. Jakarta : PenebarSwadaya

Setyanigsih, D. (2010). Analisis sensori untuk Industri Pangan dan Argo. Bogor: IPB Press.

Slamet, M. T. (2014). Dasar-dasar Kewirausahaan: Teori dan Praktik. Jakarta: Index.

Sofiah, B. D., Achyar, T. S. (2008).Buku Ajar Kuliah Penilaian Indra. Jatinangor: Universitas Padjadjaran.

Sugiyono. (2014). Statistika untuk Penelitian.

Bandung: Alfabeta.

Suyanti. (2008). Membuat Mi Sehat. Penebar Swadaya. Jakarta.

Taufik, Amir. (2011). Manajemen Strategi. Jakarta: Kharisma Putra Utama Offset. 